\title{
GEMA DI WAKTU SUBUH
}

\author{
Yogi Elga Rianggi, Rafiloza, dan Wilma Sriwulan \\ Minat Penciptaan Seni Musik, Program Pascasarjana, \\ Institut Seni Indonesia Padangpanjang, Sumatera Barat, Indonesia. \\ Email: 40913r@gmail.com, HP.081319112165
}

\begin{abstract}
Gema di Waktu Subuh (in English, it's translated into Echo at the Dawn Time) is the work of multimedia music with the method of sound exploration in the form of sounddesign composition. This composition consists of manipulative sounds that describe the atmosphere occurring at the time of Subuh prayer in Salayo Tanang Bukit Sileh, Lembang Jaya sub-district, Solok district. This composition includes in illustration music that explores the sounds of nature at dawn such as river sound, cicada's sound, rooster's sound, vehicle sound, the sound of people's reciting verses in Quran, and Shalawat Tahrim as the sign of the entrance of Subuh prayer time. Gema di Waktu Subuh was processed through the application of Digital Audio Workstation (DAW) cubase5 with the assistance of Virtual Sound Technology (VST) namely Waves 9, processed with producing 3d sound.
\end{abstract}

Keywords: Multimedia Music, Manipulation, Exploration, Breaking Dawn Echo.

\begin{abstract}
ABSTRAK
Gema di Waktu Subuh merupakan karya musik multimedia dengan metode eksplorasi bunyi dalam bentuk penggarapan Sound Design. Karya ini merupakan suarasuara manipulasi yang menggambarkan suasana yang terjadi ketika akan masuknya waktu sholat subuh di daerah Salayo Tanang Bukit Sileh Kecamatan Lembang Jaya Kabupaten Solok .Karya ini termasuk musik ilustrasi mengeksplorasi suara-suara Alam diwaktu subuh, seperti: bunyi sungai, bunyi jangkrik, bunyi ayam berkokok, bunyi kendaraan, bunyi orang yang membacakan Tilawah ayat suci Al-Qur'an, dan Shalawat Tahrim sebagai penanda masuknya waktu sholat Subuh.Gema di Waktu Subuh diolah melalui sarana pengaplikasian Digital Audio Workstation (DAW) cubase5 dengan bantuan Virtual Sound Technology (VST) yaitu Waves 9, diolah dengan menghasilkansuara $3 d$ sound.
\end{abstract}

Kata kunci: Musik-Multimedia, Manipulasi, Eksplorasi, Gema-Shubuh.

\section{PENDAHLUAN}

Secara umum audio merupakan salah satu elemen penting yang bersifat dapat di dengar dan ikut berperan dalam membangun sebuah sistem komunikasi dalam bentuk suara, berupa sinyal elektrik yang akan membawa unsur bunyi di dalamnya. Seiring dengan perkembangan teknologi dan pemikiran saat sekarang ini banyak ditemukan berbagai pengolah audio, baik dibidang musik maupun di bidang audio lainnya.

Seorang professor mechanical and aerospace enggineering, Edgar Choueiri, di Princeton University 
mengembangkan sistem recording binaural bisa menangkap detail suara lebih tajam, hasil tangkapan dari recording binauralini terdengar lebih hidup. Sistem binaural recording atau di sebut juga audio 3D bisa di dengar melalui perangkat oculist rift, soni murpeus Samsung gear dan beberapa versi dengan merek lainnya, teknologi dari 3D sound ini unuk karena mampu meniru cara kerja kepala manusia. 3d sound merupakan hasil sebuah rekamam audio manipulasi yang jika di dengarkan melaluiheadphone monitoringatau speaker yang mendukung kapasitas binauralakan terdengar seolah olah kejadian tersebut sedang dialami oleh pendengar.

Gema di Waktu Subuh kreatif idenya terinspirasi dari keadaan terbangun dari tidur pada subuh hari kemudian terdengar fenomena bunyibunyian alam subuh hari, di perkampungan daerah selayo tanang Bukit Sileh Kecamatan Lembang Jaya Kabupaten Solok. Karya yang merupakan sebuah pengolahan dari Musik Digital. Musik digital merupakan audio yang dihasilkan dari proses modulasi kode pulsa (Pulse Code Modulation) dan sinyal-sinyal digital. Dalam Proses selanjutnya, sinyal ini diolah melalui proses Analog to Digital Conversion (ADC) maupun Digital to Analog Conversion (DAC), untuk selanjutnya disimpan dalam format WAV (Prabawai, 2011:4).

WAV adalah singkatan dari istilah bahasa Inggris Wave Frome Audio Format berkas audio yang dikembangkan oleh Microsoft dan IBM. Melalui perangkat lunak (software) atau aplikasi musik digital berupa DAW (Digital Audio Workstation), alat yang bersifat digital yang memudahkan komposer atau arranger, sound engineer (SE) dalam melakukan pekerjaannya. Dengan nama aplikasi pengolahan nya Cubase5.

Di dalam Cubase5 ini terdapat VST (Virtual Sound Technology) yang membantu dalam proses pengolahan pengolahan atau penambahan suara, bagian VST (Virtual Sound Technology) yang pengkarya gunakan adalah Waves 9, berfungsi sebagai pengembang dan pemprosesan sinyalaudio dan efek audio untuk digunakan dalam pengolahan bunyi rekaman. langkah langkah pengoperasian melalui beberap software tersebut kemudian diolah menjadi sebuah suasana subuh yang terdengar $3 d$ sound.

\section{STUDI LITERATUR}

Studi literatur ini berkaitan dengan berbagai tulisan yang berkaitan dengan ketertarikan karyadi antaranya Amin (2016) dengan judul "Pembuatan Audio Untuk Mengolah Sinyal Input dari Handphone "Amin memaparkan pendengaran merupakan indra yang sangat penting untuk manusia, karena dengan kemampuan mendengar ini manusia bisa saling bertukar informasi melalui bunyi. Selain sebagai jalan bertukar informasi, bunyi juga sering dipakai untuk hiburan melalui musik.

Kim dan Park (2008) dalam judul artikelnya "3D Sound Manipulation: Theory and Application" Kim dan Park berasumsi tujuan manipulasi suara 3 dimensi (manipulasi suara 3D) adalah untuk menghasilkan bidang suara yang diinginkan atau kesan yang diinginkan 
pada posisi atau wilayah yang kita inginkan.

Kutipan dari Fiantika, Budayasa dan Lukito (2017) yang berjudul "Membangun Defenisi Genetis Kubus Melalui Distorsi Dan Manipulasi Objek Spasial" mereka menulis Manipulasi menurut Buss (1992), Manipulation, the third proposed class of mechanisms, is defined as the means by which individuals intentionally (although not necessarily consciously) influence, alter, or shape those selected environments. Artinya manipulasi adalah sarana dimana individu dengan sengaja (walaupun tidak harus sadar) mempengaruhi, mengubah, atau bentuk yang dipilih lingkunga. Pendapat ini mengisyaratkan terdapat suatu cara atau teknik yang sengaja digunakan oleh seseorang untuk mempengaruhi, mengubah objek untuk tujuan tertentu.

\section{METODE PENELITIAN}

Dalam penggarapan karya musik multimedia yang berjudul Gema di Waktu Subuh, pengkarya menggunakan beberapa metode diantaranya:

a. Metode awal persiapan yaitu metode yang sebelumnya dirancang dan difikirkan jauh-jauh hari dengan tujuan bagaimana karya ini akan dibentuk.

b. MetodeEksperimentasiyaitu pengkarya mencoba bereksperimen dengan percobaan yang bersistem dan sudah di persiapkan secara terencana. Maksudnya pengkarya mulai mengerjakan dan bereksperimen dengan medianya untuk membuat sebuah karya bunyi yang diolah sampai karyanya selesai dikerjakan (Poerwadarminta, 2008: 350).

c. Metode Perwujudan yaitu merupakan suatu proses penyampaian dalam bentuk atau rupa yang dapat dirasakan dan didengarkan. Dalam metode inilah, karya ini akan ditampilkan dan diperdengarkan kepada pendengar sehingga karya tersebut bisa bermanfaat, bisa menjadi suatu bunyi yang memanipulasi keadaan menjadi menenangkan dari berbagai kombinasi bunyi yang di gabungkan. terutama menjadi apresiasi bagi pendengar nantinya.

\section{HASIL PEMBAHSAN}

Dengan proses Mixing, mastering di perangkat yang menunjang untuk mengimbangi bunyi yang sumbang. Mixing, mastering, dan produksi, yang didirikan pada tahun 1992 oleh Gilad Keren dan Meir Sha'ashua, sebelum proses mixing, masteringpengkarya mengolah bunyi yang telah di gabungkan menggunakan Sequencer, aplikasi yang memiliki fungsi untuk merekam, mengedit, dan mengolah menjadi beberapa track sehingga proses pembuatan karya bisa berjalan.

Sequencer yang pengkarya gunakan dalam mengolah sound yaitu Cubase 5, Pengolahan dari Cubase 5 dan memamfaatkan VST (Virtual Sound Technology) akan menghasilkan bunyi seperti suasana di subuh hari yaitu bunyi sungai, bunyi jangkrik, bunyi ayam berkokok, bunyi kendaraan, bunyi orang yang membacakan Tilawah ayat 
suci Al-Qur'an, Shalawat Tahrim yang menandakan sebentar lagi waktu sholat akan masuk, dan dilanjutkan suara azan yang di dalam lafas pada azan subuh terdapat bacaan Ash-Sholatu Khoirum Minan Naum yang menjadi ciri khas dan pembeda antara waktu azan dalam penanda waktu sholat.

Bagian-bagian bunyi yang akan dibentuk kemudian dijadikan fokus penyusunan dan diolah menjadi pokok tujuan pada karya Gema di Waktu Subuh diantaranya:

a. Bunyi Sungai

Pada bagian sampel bunyi sungai, bunyi sungai yang pengkarya olah menghasilkan bunyi yang terdengar sayup-sayup, selain juga terdengar suara jangkrik di dekat rumah, bunyi sungai disini berjarak kira-kira 7 meter dari jarak pendengaran. Bunyi sungai menjadi patokan yang dikaitkan sebagai bunyi pengiring keadaan tempat sebelum bunyi-bunyi lainnya.

b. Bunyi Jangkrik

Pada bagian sampel bunyi jangkrik, pengolah merangkup sebagai bunyi hias, pengembangan yang menekankan bunyi jangkrik tersebut menjadi bagian pokok pertama yang harus di munculkan dalam mendukung suasana dikala subuh di lokasi perkampungan atau perdesaan.

c. Bunyi ayam berkokok

Pada bagian sampel bunyi ayam berkokok ini, hasil bunyi yang pengkarya olah terdengar cukup kompetibel yakni terdengar sesuai lingkup tempat perumahan yang lokasinya berjarak-jarak. Dan menjadi hal pokok kedua untuk mendukung keadaan subuh hari, dimana bunyi ayam berkokok akan menandakan waktu subuh dan menggantikannya dengan waktu fajar yang akan terbit.

d. Bunyi Kendaraan

Pada bagian sample bunyi kendaraan, dihadirkan untuk menambah kesan nyata dari sebuah keadaan lokasi. Diolah dengan bunyi jarak yang terdengar samar-samar yang pada awalnya sedikt terdengar kemudian makin keras kemudian berlalu seperti kendaraan lewat di jalan.

e. Bacaan Tilawah Al-Quran

Pada bagian sample bunyi Tilawah Al-Quran, hasil bunyi seperti halnya ketika orang membacakan Al-Quran dari beberapat Mesjid dan Mushalla yang diolah secara tahapan menghadirkan bunyi dari beberapa Mesjid dan Mushalla yang berlainan jarak dan tempat.

f. Shalawat Tarhim

Pada bagian sampel bunyi Shalawat Tarhim, bunyi ini akan menandakan azan sebentar lagi akan berkumandang sekaligus waktu sholat telah masuk. Bunyi Shalawat Tahrim sama dengan pembacaan Tilawah Al-Quran yang di dengar dari Masjid dan Mushalla yang berlainan jarak dan Tempat. 


\section{g. Azan}

Pada bagian sampel bunyi Azan adalah bunyi pada bagian terakhir yang menggambarkan bunyi keadaan subuh sebagai penanda waktu sholat telah masuk. Bunyi ini dihadirkan hampir sama dengan Shalawat Tarhim dan pembacaan Tilawah Al-Quran yang di dengar dari Masjid dan Mushalla yang berlainan jarak dan Tempat.

Pengembang konsep ini di tujukan untuk mengilustrasikan sebuah kejadian atau musik itu sendiri, Musik Ilustrasi adalah sebuah karya musik untuk melengkapi serta menghidupkan suasana dari sebuah acara baik siaran radio maupun televisi. Ketika video dan radio belum ada, musik ilustrasi biasanya digunakan untuk mengiringi sebuah pertunjukan seperti drama, teater, tablo, tarian, pergelaran muppet (wayang) dan lain lain. Musik iringan juga dapat berarti ilustrasi, tetapi ilustrasi musik tidak selalu berupa iringan dari sebuah eksplorasi bunyi dan yang lainya (Kusumawati, 2009: 3).

Ismet (2015) Skripsi. Ilustrasi Tupai JanjangI SI Padangpanjang. Karya ilustrasi tupai janjang ini memberikan nuansa musik yang menarik, karena pengkarya mencoba memadukan unsurunsur musik konvensional dan musik tradisional Minagkabau dengan menggunakan teknik-teknik dari orkestrasi musik yang menggunakan komputer sebagai tempat pengolahannya dengan menciptakan sebuah musik ilustrasi dari cerita Tupai Janjang di mana musik tersebut seolah-olah menceritakan kembali Tupai Janjang dengan mengembangkan sebuah tema pokok yang diambil dari melodi kesenianTupai Janjang.

Zaini (2015) Skripsi War of Imagination World ISI Padangpanjang Karya ini berbentuk komposisi musik elektronik yang mencoba menghadirkan suasana perang dengan menggunakan perangkat multimedia berupa software dan hardware. Karya ini mengangkat fenomena yang terjadi pada sebuah perperangan dimasa lampauyaitu $\mathrm{Pe}$ rang Paderi. Karya ini pada dasarnya adalah eksplorasi dan eksperimen dari suara-suara yang sudah diolah, dengan bahan bakunya bersumber dari suara VST (VirtualSound Technology) dengan menggunakan Nuendo sebagai wadah pengolahannya dengan output menggunakan teknologi surround sound yaitu suara yang berputar vertical dan horizontal.

Kuswari (2017) Skripsi Suasana Pantai Dari Pengembangan Metode Petikan Gitar ISI Padangpanjang Karya ini menjadikan eksplorasi sebagai metode penciptaan dengan mengembangkan bunyi gitar menjadi musik fenomena pantai.

Merekam sound langsung dari sebuah instrumen, dengan cara mentransfer bunyi langsung ke dalam souncard komputer atau laptop yang digunakan, misalkan ; gitar elektrik, dan bass elektrik, atau pilih Add Midi Track, jika ingin merekam sound yang berbentuk midi file, contoh; keyboard dan midi controller, atau dengan cara drag atau tarik sampling dari file yang sudah ada sebelum nya ke jendela kerja Cubase 5, sehingga nanti nya Cubase 5 akan secara otomatis membuat sebuah track baru yang sesuai dengan format dari 
data audio yang di tarik tersebut, untuk lebih jelas lihat gambar di bawah ini :

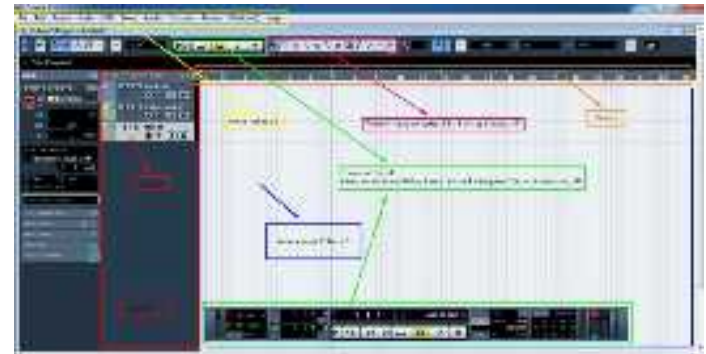

Gambar 1

Jendela Cubase 5 Track dan tool navigasi

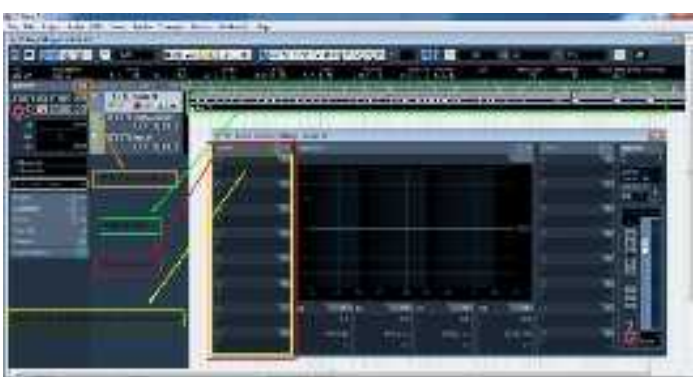

Gambar 2

Jendela Cubase 5 insert VST Plugin Efek

Di bawah ini pengolah bunyi menggunakan Virtual Sound Technology (VST)Waves 9 Sebagai wadah manipulasi ruang dan warna bunyi, pada Cubase 5 diantaranya:

\section{Bunyi sungai}

Mengolah bunyi sungai atur volume suara yang dikeluarkan sebesar $37.02 \mathrm{~m}$ dan rata penyeimbang suara kiri (L) 2 kemudian pilih icon edit chanel settings, kemudian atur equalizer seperti:

a. titik eq1 mengarah pada $14.6 / 41.0 \mathrm{~Hz}$

b. titik eq2 mengarah pada $4.0 / 3436.0 \mathrm{~Hz}$

c. titik eq3 mengarah pada $13.8 / 184.0 \mathrm{~Hz}$ d. titik eq1 mengarah pada 8.6/845.0 Hz

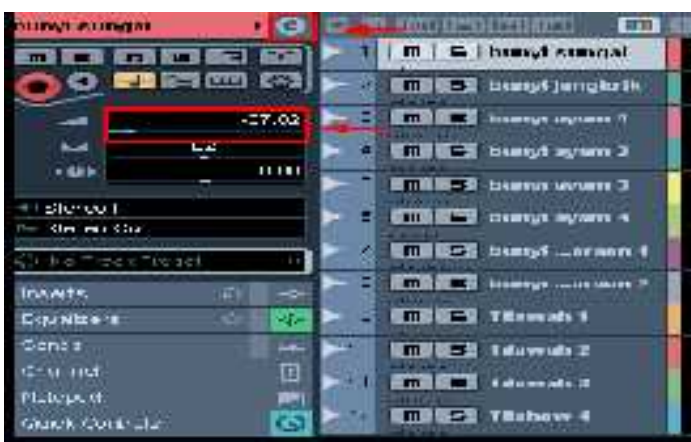

Gambar 3

Mengolah Edit Channel Settings bunyi sungai

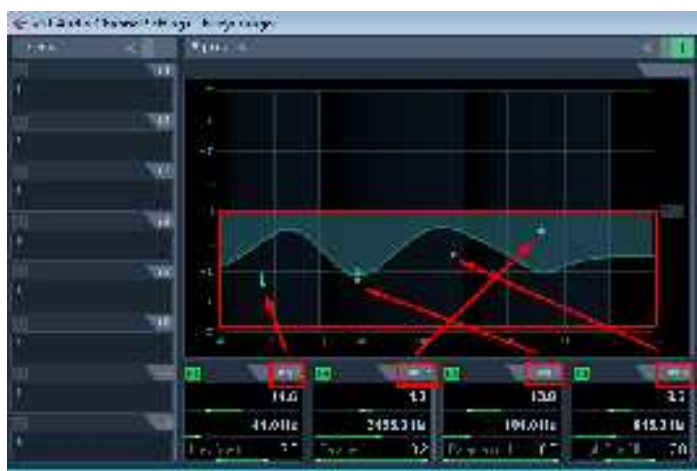

Gambar 4

Mengolah Equalizers bunyi sungai

2. Bunyi jangkrik

Mengolah bunyi jangkrik, atur volume suara sebesar -1.41 dan rata penyeimbang suara kiri (L) 19, pilih icon Edit Channel Settings, kemudian atur Equalizers seperti:

a. titik eq1 mengarah pada $20.4 / 63.0 \mathrm{~Hz}$

b. titik eq2 mengarah pada $16 / 283.0 \mathrm{~Hz}$

c. titik eq3 mengarah pada $14.8 / 3680.0 \mathrm{~Hz}$

d. titik eq4 mengarah pada 14.8/10806 Hz 


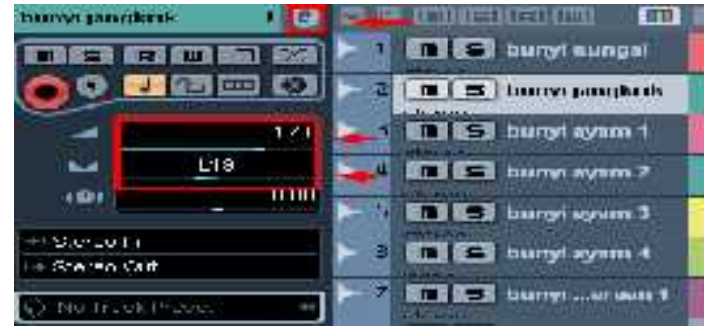

Gambar 5

Mengolah Edit Channel Settings bunyi jangkrik

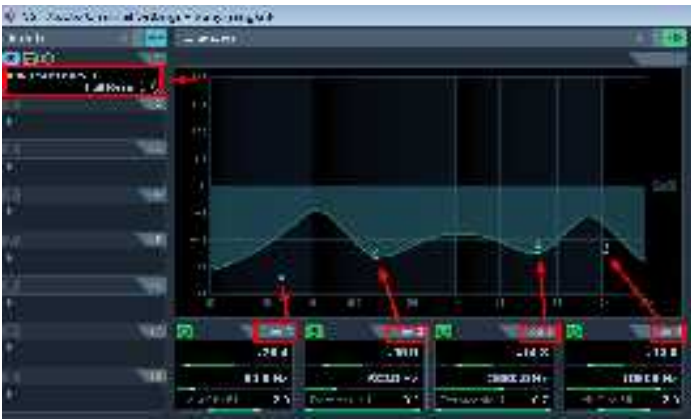

Gambar 6

Mengolah Equalizers bunyi jangkrik

Pengolahan Equalizers selanjutnya mengolah bunyi dengan memasukkan VST (Virtual Sound Technology) pada kolom inserts, akan muncul menu effeck VST (Virtual Sound Technology) pilih surround kemudian pilih R360 Stereo/5.0. pada kolom R360 Stereo/5.0 pilih effeck sound selanjutnya A: Long Dark* lalu atur titik yang ada seperti:

a. Reverb Damping $(\mathrm{Hz})$ pada arah tanda putih menjadi Freqnya 16 Rationya 0.10 arah tanda kuning Freqnya 1000 Rationya 0.11

b. Time Response (ms) Reverb Time 0.26

c. Reveb $\mathrm{Eq}(\mathrm{Hz})$ pada arah bintang orange menjadi Freqnya 996 Gainnya -24.0 arah bintang hijau Freqnya 7191 Gainnya 0.0

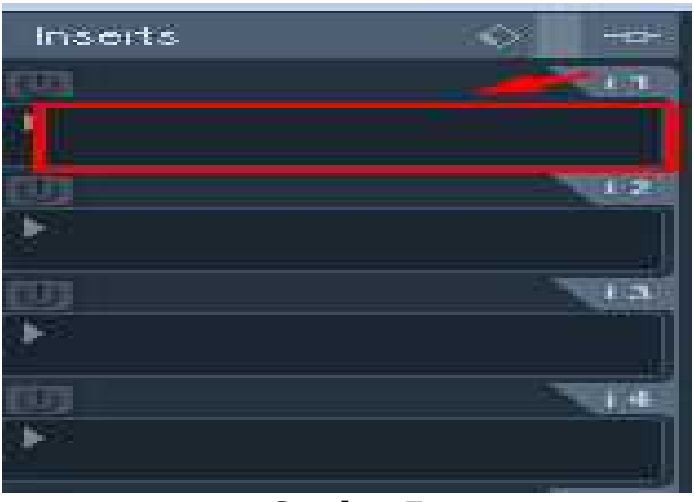

Gambar 7

Memasukkan effeck Vst

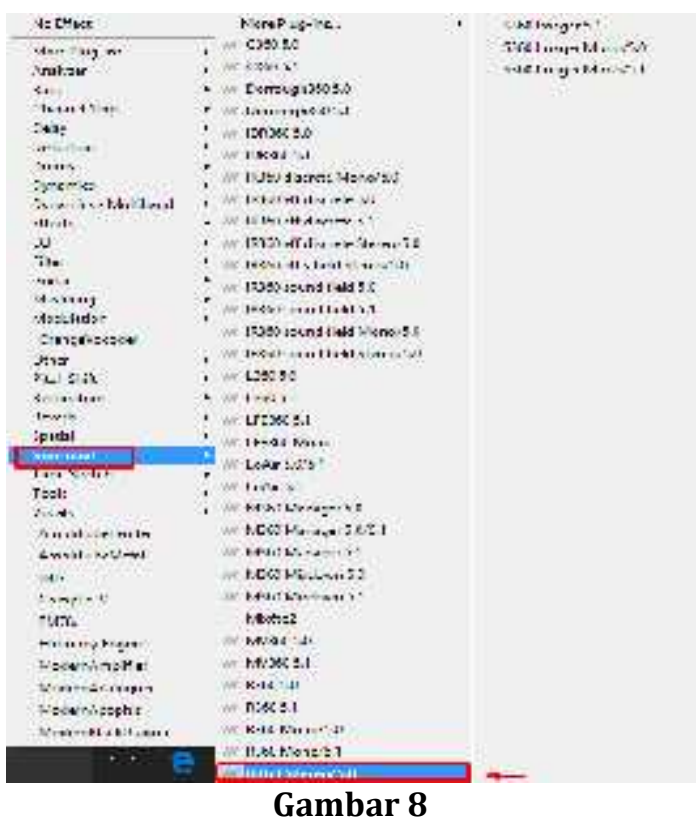

Pilihan effeck dari Vst

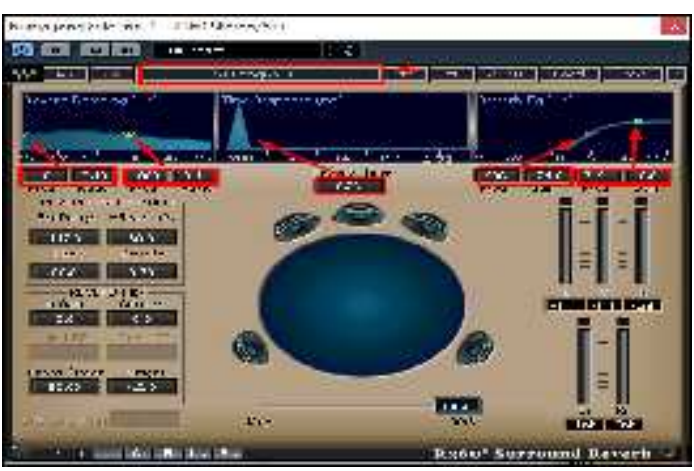

Gambar 9

Pengaturan R360 Stereo/5.0 bunyi jangkrik 
3. Bunyi ayam

Terdapat empat bunyi yang akan diolah, cara pengolahannya masih sama tetapi perbedaannya terdapat pada pengaturan volume suara, rata keseimbang kiri-kanannya. kemudian mengatur kecocokan pembentukan angka Equalizer dan effeck Vst Waves 9.

4. Bunyi kendaraan

Terdapat 2 buah bunyi yang akan diolah, yaitu bunyi motor dan truck, cara pengolahannya masih sama tetapi perbedaannya juga terdapat pada pengaturan volume suara, rata keseimbang kiri-kanannya. Kemudian mengatur kecocokan pembentukan angka Equalizer dan efek Vst Waves9. Lebih lengkapnya sebagai berikut:

a. Pada bagian bunyi kendaraan 1 (bunyi motor), volume suaranya sebesar -17.31 rata keseimbangan kanan (R) 13, mengatur Equalizer Bunyi ayam 1 menjadi:

1) titik eq1 mengarah pada $2.6 / 25.0 \mathrm{~Hz}$

2) titik eq2 mengarah pada $7.4 / 66.0 \mathrm{~Hz}$

3) titik eq3 mengarah pada 9.6/347.0 Hz

4) titik eq4 mengarah pada $24.0 / 1319.0 \mathrm{~Hz}$

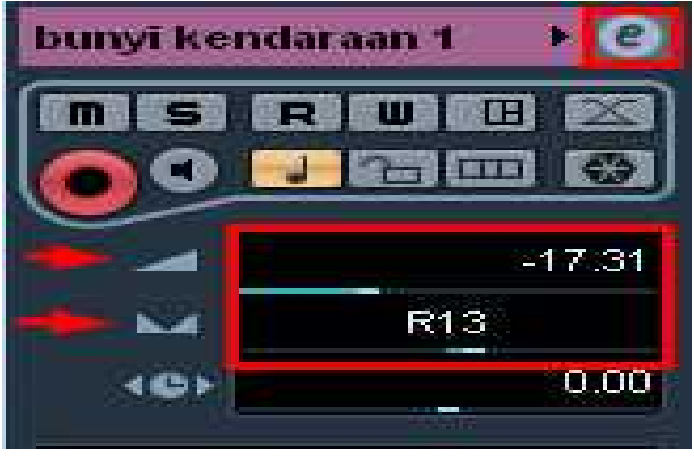

Gambar 1

Mengolah Edit Channel Settings bunyi kendaraan 1

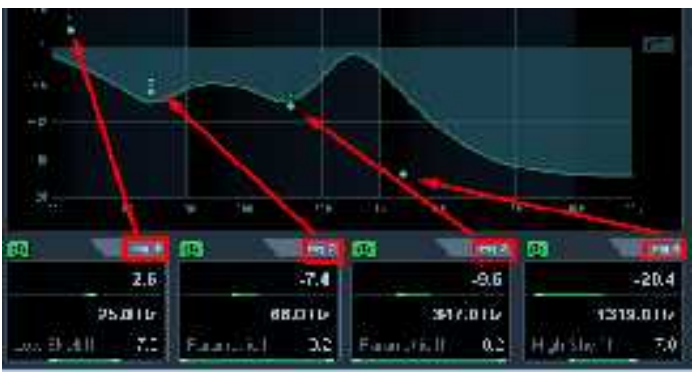

Gambar 11

Mengolah Equalizer bunyi bunyi kendaraan 1 Pada pengembangan Masararti GRP stereo Effect sound A:Setup*

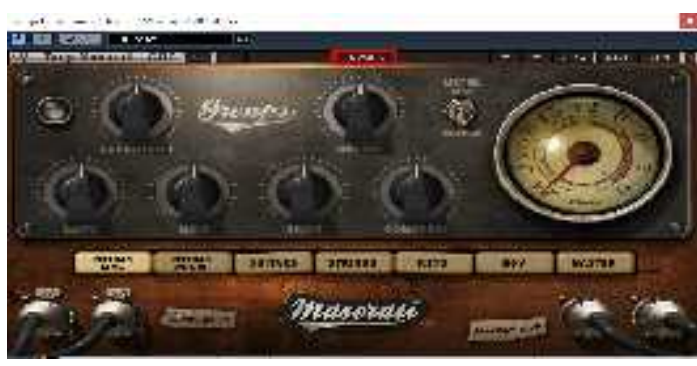

Gambar 12

Masararti GRP stereo bunyi kendaraan 1

5. Bacaan Tilawah Al Qur'an

Terdapat 4 buah bunyi yang akan diolah, cara pengolahannya masih sama tetapi perbedaannya terdapat pada pengaturan volume suara, rata keseimbang kiri-kanannya. kemudian mengatur kecocokan pembentukan angka Equalizer dan efek Vst Waves9. Lebih lengkapnya sebagai berikut. 
a. Pada bagian Tilawah 1, volume suaranya sebesar -18.59 rata keseimbangan kiri (L) 26, menga-tur Equalizer Bunyi ayam 1 menjadi:

1) titik eq1 mengarah pada $24.0 / 40.0 \mathrm{~Hz}$

2) titik eq2 mengarah pada $16.2 / 181.0 \mathrm{~Hz}$

3) titik eq3 mengarah pada $15.4 / 12181.0 \mathrm{~Hz}$

4) titik eq4 mengarah pada $12.8 / 763.0 \mathrm{~Hz}$

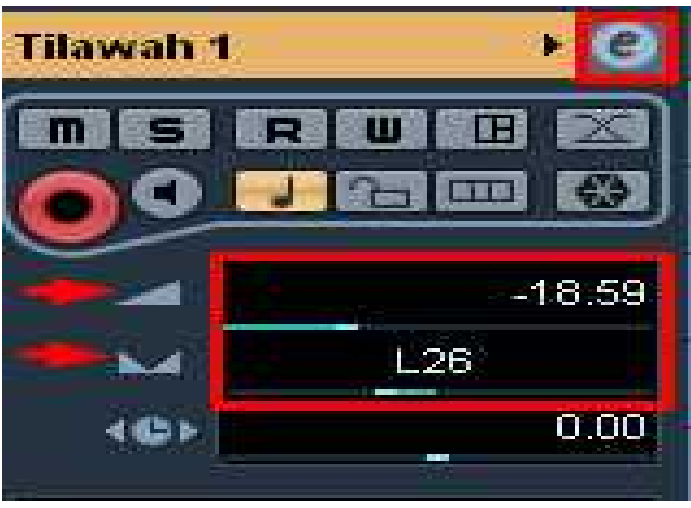

Gambar 13

MengolahEdit Channel Settings Tilawah 1

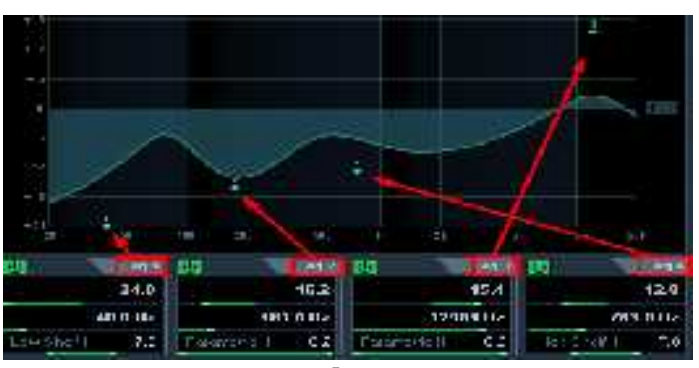

Gambar 14

Mengolah Equalizer Tilawah 1

Pada kolom R360 Stereo/5.0 pilih effeck soundA: Boom Hall * dengan mengatur polo titik effeknya seperti:

1) Reverb Damping ( $\mathrm{Hz})$ pada arah tanda putih menjadi Freqnya 20.7 Rationya 0.10 arah tanda kuning Freqnya 1003 Rationya 0.10

2) Time Response (ms) Reverb Time 2.38

3) Reveb $E q(\mathrm{~Hz})$ pada arah bintang orange menjadi Freqnya 646 Gainya -24.0 arah bintang hijau Freqnya 1025 Gainnya -23.7

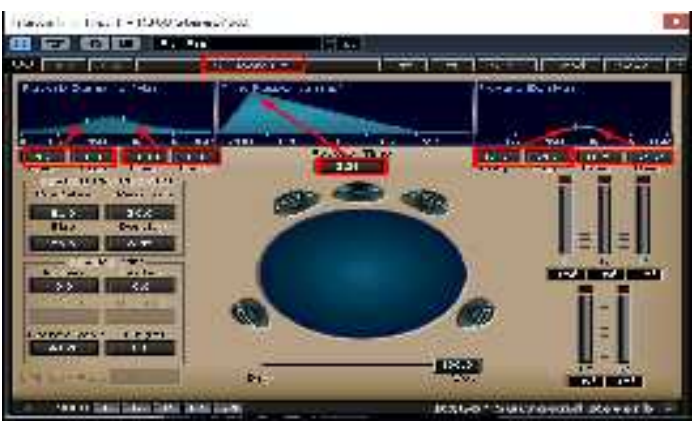

Gambar 15

Pengaturan R360 Stereo/5.0 Tilawah 1

6. Shalawat Tahrim

Terdapat 4 buah bunyi yang akan diolah, cara pengolahannya masih sama tetapi perbedaannya terdapat pada pengaturan volume suara, rata keseimbang kirikanannya. kemudian mengatur kecocokan pembentukan angka Equalizer dan efek Vst Waves 9. Lebih lengkapnya sebagai berikut.

a. Pada bagian Shalawat Tahrim 1, volume suaranya sebesar -24.98 rata keseimbangan kiri (L) 26, mengatur Equalizer Bunyi ayam 1 menjadi:

1) titik eq1 mengarah pada $24.0 / 40.0 \mathrm{~Hz}$

2) titik eq2 mengarah pada $16.2 / 181.0 \mathrm{~Hz}$ 
3) titik eq3 mengarah pada $15.4 / 12181 \mathrm{~Hz}$

4) titik eq4 mengarah pada $12.8 / 763.0 \mathrm{~Hz}$

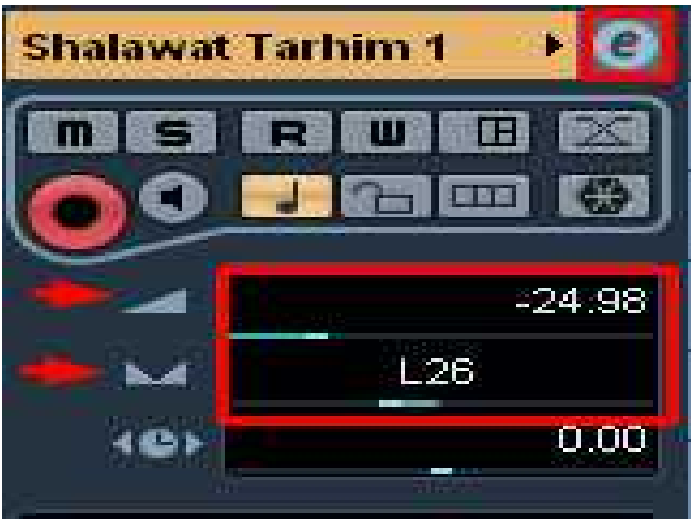

Gambar 16

Mengolah Edit Channel Settings Shalawa Tarhim 1

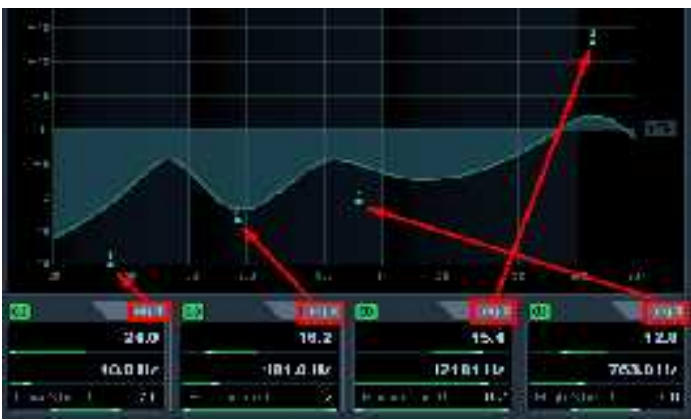

Gambar 17

Mengolah Equalizer Shalawat Tarhim 1

Pada kolom R360 Stereo/5.0 pilih effeck soundA: Boom Hall* dengan mengatur polo titik effeknya seperti:

1) Reverb Damping $(\mathrm{Hz})$ pada arah tanda putih menjadi Freqnya 207 Rationya 0.10 arah tanda kuning Freqnya 1003 Rationya 0.10

2) Time Response (ms) Reverb Time 2.38

3) Reveb $E q(\mathrm{~Hz})$ pada arah bintang orange menjadi
Freqnya 646 Gainnya -24.0 arah bintang hijau Freqnya 1025 Gainnya -23.7

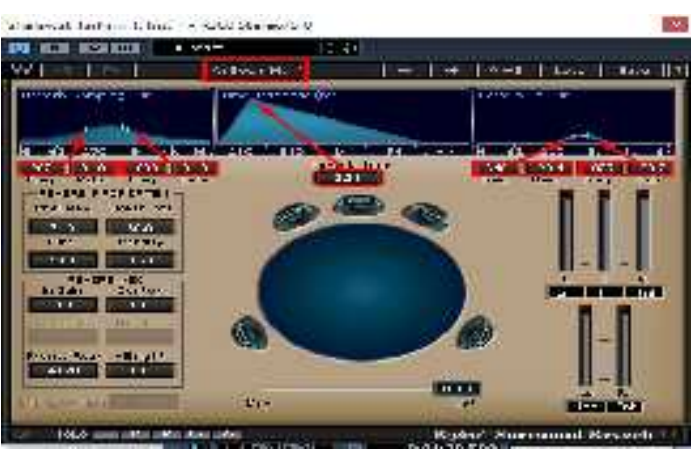

Gambar 18

Pengaturan R360 Stereo/5.0 Shalawat Tahrim 1

7. Azan

Terdapat empat bunyi yang akan diolah, cara pengolahannya masih sama tetapi perbedaannya terdapat pada pengaturan volume suara, rata keseimbang kiri-kanannya. kemudian mengatur kecocokan pembentukan angka Equalizer dan efek Vst Waves 9. Lebih lengkapnya sebagai berikut.

a. Pada bagian Adzan 1, volume suaranya sebesar -18.59 rata keseimbangan kiri (L) 26, mengatur Equalizer Adzan 1 menjadi:

1) titik eq1 mengarah pada $24.0 / 40.0 \mathrm{~Hz}$

2) titik eq2 mengarah pada $24 / 45.0 \mathrm{~Hz}$

3) titik eq3 mengarah pada $23.0 / 542.0 \mathrm{~Hz}$

4) titik eq4 mengarah pada $24.0 / 1093.0 \mathrm{~Hz}$ 


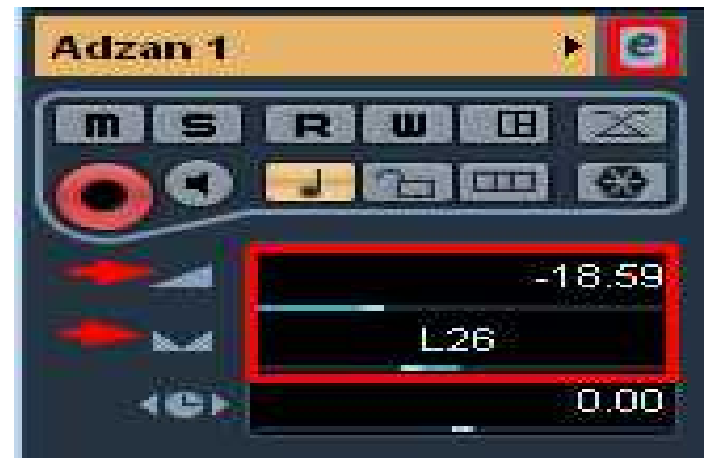

Gambar 19

Mengolah Edit Channel Settings adzan 1

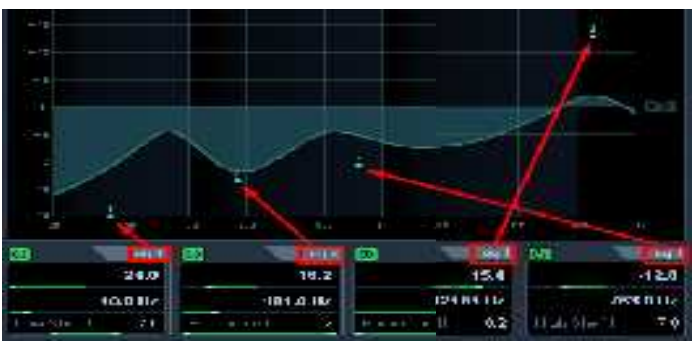

Gambar 20

Mengolah Equalizer adzan 1

Pada kolom R360 Stereo/5.0 pilih effeck soundA: Boom Hall* dengan mengatur polo titik effeknya seperti :

1) Reverb Damping $(\mathrm{Hz})$ pada arah tanda putih menjadi Freqnya 207 Rationya 0.10 arah tanda kuning Freqnya 1003 Rationya 0.10

2) Time Response (ms) Reverb Time 23.8

3) Reveb $E q(\mathrm{~Hz})$ pada arah bintang orange menjadi Freqnya 646 Gainonya -24.0 arah bintang hijau Freqnya 1025 Gainnya -23.7

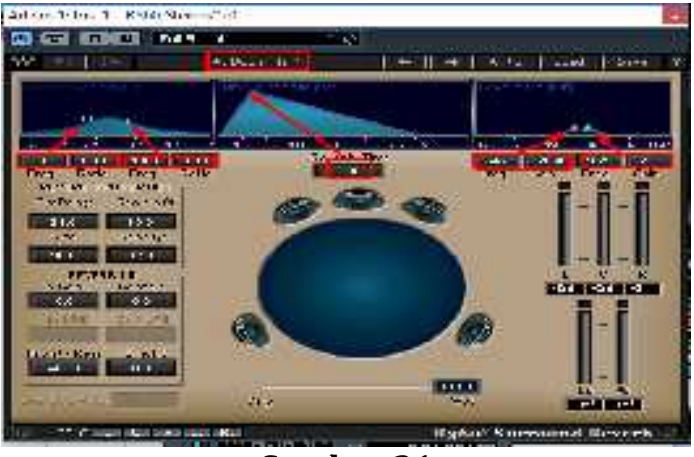

\section{Gambar 21}

Pengaturan R360 Stereo/5.0 adzan 1

\section{KESIMPULAN}

Begitu banyak pengaturan dan jenis sound yang dapat menghasilkan sebuah karya yang disediakan oleh Virtual Sound Tehnology (VST) yang digarap dengan media laptopatau komputer melalui Digital Audio Workstation (DAW), tidak semua orang dapat mengolahnya secara akademis, diperlukan keahlian dalam pemahaman penggunaan dan ilmu musik yang cukup mampuni untuk membuat sebuah karya, demi mendapatkan suasana yang ingin diciptakan.

Karya ini membutuhkan beberapa metode untuk menjadikan sebuah karya utuh yakni, menggunakan metode eksplorasi, eksperimen dan perwujudan. Secara teknis karya ini adalah proses dari kegiatan laboratorium. Kelebihan dari musik multimedia, disini pengkarya dapat memanipulasi sound menjadi soundgabungan yang menyerupai suara terdengar seolah olah nyata terjadi.

Pencapaian dari penciptaan karya ini adalah musik industri atau bisnis musik, sebab pada zaman sekarang musik sangat berpengaruh dalam berbagai kebutuhan, baik itu sebagai musik film, musik tari, musik teater ataupun kebutuhan musik itu sendiri, maka dari itu pengkarya 
mencoba mengimajinasikan komposisi musik multimedia ini sebagai musik ilustrasi. Karya ini diperdengarkan pada sebuah ruang dengan menggunakan beberapa buah headphone untuk menghasilkan capain suara yang bernuasa subuh secara nyata.

Selanjutnya menggunakan metode eksplorasi, eksperimen dan perwujudan yang mengawali munculnya ide penggarapan sebuah karya. Hal ini menjadi modal utama atau modal dasar agar karya tersebut lebih bisa dipahami dan ditemukan sebagai sesuatu hal yang baru terhadap penggunaan software dan hardware di dalam musik multimedia.

\section{DAFTAR PUSTAKA}

Amin, M. (2016) Pembuatan Audio Untuk MengolahSinyal Input Dari Handphone. Jurnal Teknik Mesin Politeknik Negeri Balikpapan vol. 4 nomor 2 Oktober, hal 120-129.

Andi, A. P. (2011). Kreatif membuat musik dengan Studio Digital sendiri. Semarang: Wahana Komputer.

Fiantika, F. R, Budayasa, K. dan Lukito, A (2017). Membangun Defenisi Genetis Kubus Melalui Distorsi Dan Manipulasi Objek Spasial. Jurnal elemen Universitas $\mathrm{Nu}-$ santara PGRI Kediri, Pascasarjana Universitas Negeri Surabaya vol. 3 Nomor 2 Juli 2017, hal. 130 - 137

Kim, Y.H. dan Park, Y (2008). 3D Sound Manipulation Theory And Applicatin. Daejeon Korea,15 th
International Congress on Sound and Vibration6-10 Juli, hal 1

Harjana, S. (2004). Esai dan Kritik Musik. Yogyakarta: Galang Press.

Wati, H. (2009). Musik Ilustrasi. Yogyakarta: artikel tidak di terbitka.

Poerwadarminta. (1976). Kamus Umum Bahasa Indonesia. Jakarta: Balai Pustaka.

\section{DOKUMEN}

Ismet, W. (2015). "Ilustrasi Tupai Janjang". Skripsi. Fakultas Pertunjukan: Institut Seni Indonesia Padangpanjang.

Kuswari, R. (2017). Suasana Pantai Dari Pengembangan Metode Petikan Gitar. Skripsi. Fakultas Pertunjukan: Institut Seni Indonesia Padangpanjang.

Zaini, A. (2015). "War of Imagination World". Skripsi. Fakultas Pertunjukan: Institut Seni Padang panjang.

\section{WEBSTOGRAFI}

Arif Hutria, E. M. " Ekspresoria". diakses dari

http://download.portalgaruda.org/artic le.php?article $=24941 \& \mathrm{val}=1538$, pada tanggal 16 maret 2017

Wikipedia. "Waves Audio Ltd". diakses dari

https://en.wikipedia.org/wiki/Waves_A udio. pada tanggal 9 maret 2017.

Y Wardhana, "DIGITAL AUDIO WORKSTATION (DAW)". diakses dari https://www.academia.edu/4857282/D IGITAL_AUDIO_WORKSTATION_DAW. pada tanggal 9maret 2017. 